\title{
ANALISIS HUKUM BUNGA BANK DITINJAU DARI PERSPEKTIF MAQASHID SYARIAH
}

\author{
Syarifah Isnaeni \\ Chamim Thohari \\ Email: syarifahbms@gmail.com
}

\begin{abstract}
The background of this research is the exixtance of the difference opinion between ulama and moslem scholars about the law of interest in Islam, which is until now still not discovered the solusion opinion and it make interesting for the researcher to make a research about the object more deep and more wide. But the researcher will not use Islamic law perspective as analysis basic, the researcher will use the objectives of sharia as analysis basic.This research is limited by several problems as following: (1) Why bank interest is needed by conventional banks? And (2) How is the law of interest if observed from the objectives of syariah (maqashid sharia)?This research is a library research. In this research the researcher choose to use a conceptual approach because the purposes which need to be achieved trouhg this research is to result an Islamic law thought about the law of interest which is not being bounded by the opinions or theories launched by majority of the moslem scholar. So this research can originally refer to the objectives of the sharia as what has been agreed by majority of ulama.

The results of this research there are: (1) the interest is a money amount addition which have to paid by bank to the costumer based on the loan percentage that given by bank to their customer. Bank interest is used for the Bank's operational costs, if there is no interest instrument, it is likely that the Bank will not be able to survive. And (2) there are three opinions of ulama's law judgments about the law of interest, it is forbidden (haram), permitted (halal) and dubious (shubhat). If this law opinions observed based on the objevtives of sharia, the researcher can make a conclusion that the opinion which is permit the interest is the most according to the objectives of sharia, and it is related to the concept of hifz al-nafs (take care of soul) and hifz almâl(take care of property) than the opinion whih has been forbid the interest. The permitted law of interest in the concept of hifz al-nafs (take care of soul) can be located in the dharuriyah, hajiyah and tahsiniyah degrees. While The permitted law of interest in the concept ofhifz almâl(take care of property)can be located in the dharuriyah and hajiyah degrees.
\end{abstract}

Keywords: Interest, Usury, Maqashid Sharia, hifz al-nafs (Take care of soul), hifz al-mâl (Take care of Property).

\section{PENDAHULUAN}

Pada masa sekarang ini masyarakat dihadapkan pada masalah bunga bank yang menerapkan sistem bunga pada pinjaman yang diberikan. Sistem perbankan adalah sistem keuangan yang baru ada di era modern seperti saat ini. Adapun masyarakat pada masa awal Islam belum mengenal sistem perbankan modern dalam arti praktis. Karena itu dalam menanggapi fenomena tentang hukum bunga bank ini di kalangan para ulama dan sarjana Islam terjadi perbedaan pendapat. perbedaan pandangan dalam menilai permasalahan ini menimbulkan kesimpulan-kesimpulan hukum yang berbeda pula, dalam hal boleh atau tidaknya, halal haramnya umat Islam bermu'amalah dengan bank. 
Jika kembali kepada ajaran Islam di mana al-Quran sendiri telah melarang bentuk mu'amalah yang mengandung unsur riba. Dasar persoalan riba dapat diketahui dengan jelas dan tegas dalam 3 ( tiga) tempat, yakni dalam al-Quran surat al-Rum ayat 39, dalam surat Ali Imran ayat 130, dan juga dalam surat al-Baqarah ayat 275-279. Semua ulama di dunia ini sepakat bahwa riba adalah haram. Namun ketika dihadapkan pada masalah apaka bunga bank adalah sama dengan riba, para ulama berselisih pendapat.

Misalnya saja di kalangan ulama Nahdhatul Ulama terdapat tiga pendapat, ${ }^{1}$ yakni:

1. Haram: sebab termasuk hutang yang dipungut manfaatnya (rente);

2. Halal: sebab tidak ada syarat sewaktu akad, menurut ahli hukum yang terkenal bahwa adat yang berlaku itu tidak termasuk menjadi syarat; dan

3. Syubhat (tidak tentu haram halalnya): sebab para ahli hukum masih terjadi selisih pendapat.

Adapun Muhammadiyah yang dalam masalah ini diwakili oleh lembaga fatwanya, yakni Majelis Tarjih. Dalam menetapkan hukum bunga bank, Majlis Tarjih mangaitkannya dengan masalah hukum riba, yakni apakah bunga bank dapat dipersamakan dengan riba atau tidak. Untuk memastikan jawaban tersebut, Majelis Tarjih menggunakan qiyas sebagai metode ijtihadnya. Bagi Muhammadiyah 'illat diharamkannya riba adalah adanya eksploitasi atau penganiayaan (al-zulm) terhadap peminjaman dana. Konsekuensinya, kalau illat keharaman riba tersebut terdapat pada bunga bank, maka bunga bank sama dengan riba dan hukumnya riba. Sebaliknya kalau 'illat itu tidak ada pada bunga bank, maka bunga bank bukan riba, sehingga hukumnya tidak haram.

Bagi Muhammadiyah 'illat diharamkannya riba disinyalir sedikit banyak juga ada pada bunga bank, sehingga bunga bank disamakan dengan riba dan hukumnya adalah haram. Namun keputusan tersebut hanya berlaku untuk bank milik swasta. Adapun bunga bank yang diberikan oleh bank milik pemerintah pada para nasabahnya atau sebaliknya, termasuk perkara musytabihat (meragukan), tidak haram dan tidak pula halal secara mutlak. ${ }^{2}$

Tidak hanya NU dan Muhammadiyah, para ulama kontemporer pun berselisih pendapat tentang hukum bunga bank. Dalam konteks ini setidaknya ada tiga kelompok ulama yang berpendapat tentang hukum bunga bank. Pertama, kelompok yang mengharamkan bunga bank karena dipersamakan dengan riba. Kedua, kelompok yang menganggap bunga bank tidak sama dengan riba, sehingga hukumnya halal. Ketiga, kelompok yang menganggap bahwa bunga bank hukumnya syubhat.pendapat ini sebagaimana pendapat para ulama di Majelis Tarjih di Muhammadiyah.

Di antara ketiga pendapat di atas yang paling dominan adalah pendapat yang pertama, yakni pendapat yang mengharamkan buang bank karena dipersamakan dengan riba yang harus dijauhi. Hal serius yang sebenarnya terjadi dalam masyarakat saat ini berkaitan erat dengan pendapat keharaman bunga bank ini. Di satu sisi umat di zaman modern hampir tidak bisa terlepas dari berinteraksi dengan dunia perbankan, namun di sisi lain tersimpan rasa ketakutan dan ketidaknyamanan akibat pendapat yang mengharamkan bungan bank tersebut. Di antara mereka ada yang beralih ke bank-bank yang berbasis syari'ah, namun kenyataannya bank-bank syari'ah tidak jauh berbeda dengan bank-bank konvensional dalam sistem keuangannya, meskipun berbeda dalam istilah pelaksanaannya. Bahkan dalam kasus tertentu bank konvensional dirasa jauh lebih manusiawi daripada bank-bank yang berlabel syari'ah. Inilah realitas yang banyak terjadi pada saat ini dimana masyarakat seharusnya mendapatkan solusi

\footnotetext{
${ }^{1}$ Lihat Keputusan MUktamar NU II di Surabaya pada tanggal 12 Rabi'ah as-Sani 1346 H atau 9 Oktober 1927 No. 28.

${ }^{2}$ Fathurrahman Jamil, Metode Ijtihad Muhamamdiyah, (Jakarta: Logos, 1995), hlm. 124-131.
} 
hukum yang benar-benar realistis terutama dalam masalah ekonomi yang menyangkut taraf hidup banyak orang, namun karena fatwa-fatwa yang tidak bersifat solutif justru semakin menyengsarakan masyarakat.

Berdasarkan realitas di atas, penelitian ini hendak mengungkapkan argumentasiargumentasi para ulama tentang hukum bunga bank dalam Islam. Setelah itu penulis akan menganalisis pendapat-pendapat ulama baik yang mengharamkan, yang menghalalkan maupun yang menganggap bunga bank adalah perkara syubhat, dari sekian pendapat tersebut manakah yang paling relevan dengan maqashid syari'ah atau tujuan-tujuan pokok syariat Islam sehingga lebih layak untuk diikuti.

Tujuan penelitian ini adalah untuk menjawab pokok-pokok permasalahan yang telah dirumuskan tersebut, yakni: 1. Mengapa bunga bank dibutuhkan oleh bank konvensional? 2 . Bagaimana hukum bunga bank ditinjau dari perspektif maqashid syariah?.

\section{METODE PENELITIAN}

Jenis penelitian ini termasuk jenis penelitian kepustakaan (library research). Sebagaimana diketahui bahwa tujuan dan kegunaan studi kepustakaan hakekatnya adalah untuk menunjukkan jalan pemecahan atas permasalahan penelitian. Apabila peneliti mengetahui apa yang telah dilakukan oleh peneliti lain, maka peneliti akan lebih siap dengan pengetahuan yang lebih dalam dan lengkap. ${ }^{3}$

Dalam penelitian ini penulis memilih menggunakan pendekatan konseptual mengingat tujuan yang ingin dicapai dalam penelitian ini adalah menghasilkan satu konsep pemikiran hukum Islam tentang hukum bunga bank yang tidak terikat oleh pandangan-pandangan atau teori-teori yang telah ada, tetapi benar-benar merujuk kepada tujuan-tujuan syariat Islam sebagaimana yang telah disepakati oleh jumhur ulama.

Dalam penelitian ini, karena objek penelitian ini adalah pandangan para ulama tentang hukum bunga bank, maka sumber data primernya tentunya adalah fatwa-fatwa resmi yang dikeluarkan oleh institusi fatwa, atau jika fatwa tersebut sifatnya personal atau berupa pandangan pribadi seorang ulama, maka sumber data primernya adalah pendapat ulama tersebut baik berupa tulisan, record, atau instrumen lainnya yang memungkinkan fatwa tersebut ter-akses.

Teknik pengumpulan data yang akan dipergunakan dalam penelitian ini adalah teknik atau metode dokumentasi. Menurut Arikunto, teknik pengumpulan data dengan dokumentasi adalah mencari data-data mengenai hal-hal atau variabel yang berhubungan dengan tema penelitian berupa catatan, transkrip, buku, surat, majalah, notulen rapat, agenda, dan sebagainya. ${ }^{4}$ Teknih pengumpulan data juga dapat dilakukan melalui media elektronik atau media sosial yang saat ini berkembang pesat seperti situs-situs atau website institusional, blog pribadi, dan lain sebagainya. Terkait dengan penelitan ini, teknik pengumpulan data yang dimaksud adalah teknik pengumpulan data dengan mengumpulkan dan mempelajari tema-tema yang menjelaskan tentang pandangan para ulama tentang hukum bunga bank, baik ulama terdahulu maupun ulama kontemporer. Selain itu untuk melihat landasan metodologis yang digunakan dalam argumentasi hukumnya, penulis juga akan mengumpulkan sumber-sumber lain yang menjelaskan tentang metodologi penetapan hukum Islam sebagai bagian dari proses pengumpulan data dalam penelitian ini.

\footnotetext{
${ }^{3}$ Bambang Sunggono, Metodologi Penelitian Hukum, (Jakarta: Rajagrafindo, 1997), lm. 112.

${ }^{4}$ Suharsimi Arikunto, Prosedur Penelitian: Suatu Pendekatan Praktik, (Jakarta: Rineka Cipta, 2002), hlm. 135.
} 
Berkaitan dengan penelitian ini, setelah pengumpulan dan verifikasi data dilakukan, maka langkah penelitian berikutnya adalah analisis data. Adapun teknik analisis yang akan digunakan dalam penelitian ini setidaknya ada dua, yakni:

1. Metode induktif, yaitu teknik analisis data dengan cara mengumpulkan dan mengelompokkan bentuk-bentuk pendapat para ulama yang bermacam-macam menjadi model-model tertentu beserta karakteristik metodologis yang digunakan tentang masalah yang diteliti dalam penelitian ini, yakni tentang hukum bunga bank.

2. Metode komparatif, yaitu mengaitkan atau melihat kesesuaian dan ketidaksesuain antara model-model pendapat ulama tersebut dengan konsep tujuan-tujuan syari'ah atau maqashid syari'ah. Jadi dalam tahap ini penulis hendak menganalisis pendapat yang manakah tentang hukum bunga bank yang sejalan atau relevan dengan maqashid syari'ah.

\section{PEMBAHASAN}

\section{A. Mengapa Bunga Bank dibutuhkan oleh Bank Konvensional}

Perbankan adalah suatu badan usaha yang bergerak dibidang jual beli uang. Untuk dapat hidup dan berkembang, maka bank membeli dana atau uang dari masyarakat dan atau pihak lain, misalnya dari Bank Indonesia yang dinamai Kredit Likuiditas. Maksudnya adalah kepada masyarakat penyimpan dana maupun kepada Bank Indonesia akan diberikan balas jasa atas pemakaian dana tersebut yang disebut dengan istilah bunga.

Untuk dapat membayar balas jasa atau bunga yang dibayarkan kepada penyimpan, maka bank akan meminjamkan pula dana tersebut dalam bentuk kredit kepada masyarakat yang membutuhkan tambahan modal usaha (bukan modal awal) untuk investasi, modal kerja, maupun perdagangan. Atas keuntungan usaha yang diperoleh debitur dengan memakai atau mempergunakan kredit dari bank, maka debitur menunjukkan tindakan yang terpuji dengan memberikan balas jasa atau bunga atas pemakaian dana tersebut kepada bank yang bersangkutan.

Selisih bunga yang diterima bank dari debitur dengan bunga yang dibayarkan kepada penyimpan dana di Bank, itulah yang menjadi keuntungan Bank. Keuntungan inilah yang dipergunakan oleh Bank untuk menutupi biaya operasionalnya antara lain untuk gaji pegawai, biaya pengobatan pegawai, biaya promosi, biaya gedung, biaya kendaraan bermotor, biaya listrik/air dan lain sebagainya.

Dapat ditambahkan bahwa kalau penyimpan dana meminta kembali dananya, maka Bank harus mengembalikannya tanpa alasan. Maksudnya biarpun simpanan nasabah tersebut sudah dipinjamkan dalam bentuk kredit kepada debitur, dan debitur karena sesuatu hal tidak dapat mengembalikan hutangnya kepada Bank, maka Bank harus dan wajib mengembalikan uang/dana penyimpan tersebut. Dari uraian ini, dapat diketahui bagaimana urgennya bunga dalam perbankan. Kalau tidak ada instrumen bunga, maka kemungkinan besar bank tidak akan mampu bertahan. Dan secara umum di suatu daerah dimana tidak ada bank yang beroperasi disana, maka akibatnya daerah tersebut akan tertinggal atau tidak berkembang.

Pada bagian ini penulis akan membahas beberapa poin penting yang berkaitan dengan mekanisme penerapan sistem bunga pada bank konvensional yang akan dijelaskan secara singkat dalam tulisan ini.

\section{Macam-macam Bunga Bank}

Dalam kegiatan sehari-hari di dunia perbankan yang menerapkan prinsip konvensional terdapat dua macam atau jenis bunga perbankan yaitu:

(1) Bunga simpanan. 
Bunga simpanan adalah bunga yang diberikan oleh bank sebagai rangsangan atau balas jasa bagi nasabah yang menyimpan uangnya di bank. Sebagai contoh jasa giro, bunga tabungan, dan bunga deposito. Bunga simpanan juga dapat diartikan sebagai harga yang harus dibayar oleh Bank kepada nasabah yang memiliki simpanan di bank.

(2) Bunga pinjaman.

Bunga pinjaman adalah bunga atau balas jasa yang dibayar oleh nasabah peminjam atau debitur - misalnya orang yang memperoleh kredit dari bank - kepada bank. Sebagai contoh bunga kredit investasi, Kredit Modal Kerja, dan Kredit Perdagangan. Bunga pinjaman juga dapat diartikan sebagai harga yang harus dibayar oleh debitur atas pinjaman kredit kepada Bank.

Kedua macam bunga ini merupakan komponen utama faktor biaya dan faktor pendapatan bagi bank yang bersangkutan. Bunga simpanan merupakan biaya dana yang harus dibayarkan kepada nasabah yang menyimpan dananya di bank, sedangkan bunga pinjaman merupakan pendapatan yang diterima dari nasabah yang telah mendapatkan kredit dari bank. Baik bunga simpanan maupun bunga pinjaman, masing-masing saling mempengaruhi satu sama lainnya.

Sebagai contoh seandainya bunga simpanan tinggi, maka secara otomatis bunga pinjaman juga terpengaruh ikut naik dan demikian pula sebaliknya, semakin rendah bunga simpanan, maka bunga pinjaman juga berpengaruh ikut turun. ${ }^{5}$

\section{Faktor-faktor yang mempengaruhi suku bunga}

Faktor-faktor utama yang mempengaruhi besar kecilnya penetapan suku bunga ${ }^{6}$ adalah sebagai berikut:

(1) Kebutuhan dana

Apabila bank kekurangan dana, sementara permohonan pinjaman meningkat, maka yang dilakukan oleh bank agar dana tersebut cepat terpenuhi adalah dengan meningkatkan suku bunga simpanan. Peningkatan suku bunga simpanan secara otomatis akan pula meningkatkan bunga pinjaman. Namun apabila dana simpanan banyak, sementara permohonan pinjaman sedikit, maka bunga simpanan akan turun.

(2) Persaingan

Dalam memperebutkan dana simpanan, maka disamping faktor promosi, yang paling utama harus pihak perbankan perhatikan adalah bank pesaing. Dalam arti jika untuk bunga simpanan rata-rata $1 \%$ perbulan, maka jika hendak mendapatkan dana cepat sebaiknya bunga simpanan dinaikkan di atas bunga pesaing, misalnya 1,25\% perbulan. Namun, sebaliknya untuk suku bunga pinjaman yaitu harus berada dibawah suku bunga bank pesaing agar dana yang tersedia di bank dapat disalurkan kepada masyarakat yang membutuhkan tambahan modal untuk pengembangan usahanya.

(3) Kebijakan pemerintah

Maksudnya adalah baik untuk bunga simpanan maupun bunga pinjaman, pihak perbankan tidak boleh melebihi bunga yang sudah ditetapkan oleh pemerintah. Maksudnya adalah ada batasan maksimal dan batasan minimal untuk suku bunga yang diizinkan oleh pemerintah. Tujuannya ditetapkan batasan maksimal dan minimal untuk suku bunga adalah agar perbankan di Indonesia dapat bersaing secara sehat.

(4) Target laba yang diinginkan bank

Target laba dari bank adalah merupakan salah satu faktor yang sangat menentukan untuk menetapkan besar kecilnya suku bunga pinjaman. Jika laba yang diinginkan besar, maka bunga pinjaman ikut besar dan bunga simpanan ditekan sekecil mungkin, demikian pula sebaliknya,

\footnotetext{
${ }^{5}$ Kasmir, Manajemen Perbankan, (Jakarta: RajaGrafindo Persada, 2010), hlm. 132.

${ }^{6}$ Ibid, hlm. 132-135.
} 
sesuai dengan target laba yang diinginkan. Akan tetapi untuk menghadapi bank pesaing, target laba harus diturunkan seminimal mungkin.

(5) Jangka waktu

Jangka waktu pinjaman atau kredit maupun simpanan sangat menentukan tinggi rendahnya suku bunga. Semakin panjang jangka waktu pinjaman, akan semakin tinggi bunganya, hal ini disebabkan besarnya kemungkinan risiko di masa mendatang. Demikian pula sebaliknya, jika pinjaman berjangka pendek, maka bunganya relatif akan lebih rendah.

Akan tetapi untuk bunga simpanan (Giro dan Tabungan) tergantung kepada besar kecilnya saldo Giro dan Tabungan, semakin besar saldonya maka semakin besar pulalah persentase (\%) suku bunganya. Sedangkan untuk Deposito, semakin panjang jangka waktunya maka semakin besar pula persentase (\%) bunganya.

\section{Mekanisme Penetapan Sistem Bunga Berdasarkan Komponen-komponennya Pada Bank Konvensional $^{7}$}

Sebelum menjelaskan bagaimana mekanisme penetapan sistem bungan pada bank konvensional, terlebih dahulu akan dibahas tentang komponen-komponen yang mempengaruhi besar kecilnya suku bunga. Adapun komponen-komponen dalam menentukan jumlah suku bunga adalah sebagai berikut:

1. Total biaya dana (Cost of Fund)

Total biaya dana adalah merupakan total bunga yang dikeluarkan oleh bank untuk memperoleh dana simpanan, baik dalam bentuk simpanan giro, tabungan, maupun deposito. Total biaya dana tersebut tergantung dari seberapa besar bunga yang ditetapkan untuk memperoleh dana yang diinginkan. Semakin besar bunga yang dibebankan terhadap bunga simpanan, semakin tinggi pula biaya dananya. Demikian pula sebaliknya, semakin kecil bunga yang dibebankan terhadap bunga simpanan, semakin kecil pula biaya dananya. Total biaya dana tersebut harus dikurangi dengan cadangan wajib atau Reserve Requirement (RR) yang telah ditetapkan oleh pemerintah. Pada saat ini besarnya RR yang ditetapkan oleh pemerintah adalah $5 \%$.

2. Biaya operasional

Dalam melakukan kegiatan usaha setiap perbankan membutuhkan berbagai sarana dan prasarana, baik berupa manusia maupun berupa alat. Penggunaan sarana dan prasarana tersebut memerlukan sejumlah biaya yang harus ditanggung oleh bank sebagai biaya operasional. Biaya operasional ini merupakan biaya yang dikeluarkan oleh bank dalam melakukan operasionalnya. Biaya ini antara lain terdiri dari biaya gaji pegawai, biaya administrasi, biaya pemeliharaan, dan biaya-biaya lainnya.

3. Cadangan risiko kredit macet

Cadangan risiko kredit macet adalah merupakan cadangan yang dipersiapkan terhadap macetnya kredit yang akan diberikan, hal ini disebabkan karena atas setiap kredit yang direalisir pasti mengandung suatu risiko tidak dibayar. Risiko ini timbul baik disengaja maupun tidak disengaja. Oleh sebab itu, pihak perbankan perlu mencadangkannya sebagai sikap berhati-hati menghadapinya dengan cara membebankan sejumlah persentase tertentu terhadap kredit yang disalurkan.

4. Laba yang diharapkan perbankan

Dalam melakukan setiap transaksi, pihak perbankan selalu ingin memperoleh atau mendapatkan laba yang maksimal. Penetapan laba yang diinginkan ini ditentukan oleh beberapa pertimbangan penting, mengingat penentuan besarnya laba sangat mempengaruhi besarnya suku

\footnotetext{
${ }^{7}$ Ibid, hlm. 135-137.
} 
bunga kredit. Dalam situasi semacam ini, biasanya pihak perbankan disamping melihat kondisi bank pesaing, juga melihat kriteria calon nasabah, apakah nasabah prima atau bukan, dan juga melihat sektor-sektor yang dibiayai, misalnya jika yang dibiayai tersebut adalah proyek pemerintah atau untuk pengusaha atau rakyat kecil, maka suku bunga kredit nya pun akan lebih rendah, berbeda dengan kredit yang sifatnya untuk komersial.

5. Pajak

Pajak merupakan kewajiban yang dibebankan pemerintah kepada pihak perbankan yang memberikan fasilitas kredit kepada nasabahnya. Untuk lebih mudah memahami pembebanan suku bunga, berikut ini contoh komponen-komponen pembebanan suku bunga dalam menentukan suku bunga kredit.

Misalnya PT. Bank Rakyat Indonesia Kantor Cabang Balerejo Kabupaten Madiun menentukan suku bunga deposito sebesar 12\% PA kepada para deposannya. Cadangan Wajib (RR) yang ditetapkan pemerintah adalah sebesar 5\%. Kemudian biaya operasional yang dikeluarkan adalah sebesar 5\% dan cadangan risiko kredit macet sebesar 1\%. Laba yang diinginkan misalnya adalah 5\% dan pajak sebesar 20\%. Hitung berapa suku bunga kredit yang diberikan (based lending rate) kepada para debiturnya (peminjam).

Jawab:

$$
\begin{aligned}
\text { Cost of Fund } & =\underline{\text { Bunga yang dibebankan }} \\
& =(12 \%) /(100 \%-5 \%) \\
& =(12 \%) /(95 \%) \\
& =12,63 \%
\end{aligned}
$$

Jadi Cost of Fund 12,63\% dibulatkan menjadi $13 \%$.

Untuk menghitung bunga kredit yang diberikan adalah sebagai berikut:

Total biaya dana (Cost of Fund) ........................... 13\%

Total biaya operasi ............................................... 5\%

Cadangan risiko kredit macet ................................ 1\%

Laba yang diinginkan ...................................... 5\%

$\mathrm{P}$ a j a k $20 \%$ dari laba $(5 \%)$............................... $1 \%$

Bunga kredit yang diberikan (based lending rate)... 25\%

Demikan deskripsi tentang mekanisme penentuan suku bunga pada bank-bank konvensional.

\section{B. Hukum Bunga Bank Ditinjau Dari Perspektif Maqashid Syariah}

Sebelum membahas tentang perdebatan ulama dalam maslaah hukum bunga bank dan perspektif maqashid syariah, penulis terlebih dahulu akan membahas istilah yang seringkali dikaitkan dengan hukum bunga bank, yakni riba.

\section{Istilah Riba}

\section{a. Pengertian Riba}

Secara etimologis, kata riba bermakna tambahan. Karena bentuk dari perbuatan riba adalah meminta tambahan dari sesuatu yang diutangkan. Karena itu riba dalam konteks perbankan disebut sebagai bunga, karena salah satu perbuatan riba adalah membuat harta, uang atau yang lainnya yang dipinjamkan kepada orang lain berlebih atau menggelembung dan bertambah besar. Raghib al-Isfahani memaknai kata riba sebagai sesuatu yang naik, bertambah, tumbuh dan berkembang. ${ }^{8}$

\footnotetext{
${ }^{8}$ Ismail Nawawi, Fiqh Muamalah Klasik dan Kontemporer, (Bogor: Ghalia Indonesiaa, 2012), hlm. 69.
} 
Definisi riba menurut al-Ma'ali adalah akad yang terjadi atas pertukaran barang atau komoditas tertentu yang tidak diketahui perimbangannya menurut syara' manakala berakad atau mengakhiri penukaran kedua belah pihak atau salah satu dari keduanya. Abdurrahman al-Zajiri adalah "Bertambahnya salah satu dari dua penukaran yang sejenis tanpa adanya imbalan untuk penukaran ini." Definisi ini mengandung pengertian bahwa riba adalah suatu kelebihan yang terjadi dalam tukar-menukar barang yang sejenis dengan tanpa disertai imbalan. Namun yang perlu diketahui adalah bahwa tidak semua bentuk tambahan atas modal pokok yang ditransaksikan tersebut dilarang dalam Islam. Seperti profit yang didapat dalam suatu usaha juga terpotensi untuk menambah nilai modal pokok, namun profit tersebut tidak dilarang dalam Islam.

Syeikh Muhammad Abduh mendefinisikan riba sebagai penambahan-penambahan yang disyaratkan oleh orang yang memiliki harta kepada orang yang meminjam hartanya, karena pengunduran janji pembayaran oleh peminjam dari waktu yang telah ditentukan. Definisi Syeikh Muhammad Abduh ini menurut penulis yang paling sesuai dengan konteks diharamkannya riba. Karena dalam konteks turunnya ayat-ayat riba, suatu perbuatan disebut riba karena adanya permintaan tambahan pembayaran dari pemilik modal kepada peminjam tanpa adanya perjanjian di awal. Artinya penambahan pembayaran dituntut secara satu pihak tanpa persetujuan peminjam. Konsep riba seperti ini dikenal dengan riba nasi'ah, dan inilah sebenarnya bentuk riba yang dilarang oleh al-Qur'an.

\section{b. Dasar Hukum Larangan Riba}

Di dalam al-Qur'an hukum tentang haramnya riba dijelaskan dalam beberapa ayat secara terpisah, yakni surat al-Rum ayat 39; surat Ali Imran ayat 130; surat al-Baqarah ayat 275 dan 278. Sedangkan di dalam Sunnah terdapat beberapa hadis yang menjelaskan larangan riba, di antaranya:

1. Hadis Abu Hurairah

Dari Abu Hurairah, Nabi saw bersabda "Jauhilah tujuh perbuatan yang merusak. Para sahabat bertanya "Ya Rasulullah apakah tujuh perbuatan tersebut?" Nabi saw menjawab "Menyekutukan Allah, sihir, membunuh juwa yang diharamkan oleh Allah kecuali dengan hak, memakan riba, memakan harta anak yatim, melarikan diripada saat pertempuran, dan menuduh wanita yang muhsan berbuat maksiat."

2. Hadis Abdullah Ibn Mas'ud

Dari Ibn Mas'ud berkata; "Rasulullah saw mengutuk orang yang memakan riba, orang yang mewakilinya, saksinya, dan orang yang menulisnya." 10

3. Hadis Abu Hurairah

Dari Abu Hurairah berkata; "Rasulullah saw bersabda: "emas dengan emas dengan timbangan yang sama dan jumlah yang sama. Dan perak dengan perak dengan timbangan yang sama dan jumlah yang sama. Barangsiapa yang menambah atau meminta tambahan maka ia adalah riba." 11

Ayat-ayat al-Qur'an dan hadis di atas tampak jelas dan tegas menyebutkan larangan perbuatan riba. Bahkan dalam hadis kedua disebutkan bahwa mereka yang memakan riba dan semua orang yang terlibat dalam transaksi riba dilaknat. Jadi semua redaksi dalil yang disebutkan di atas kiranya cukuplah sebagai dasar tentang keharaman transaksi riba.

\section{c. Klasifikasi Riba}

\footnotetext{
${ }^{9}$ Shahih Bukhari, juz 6, hadis nomor 6465.

${ }^{10}$ Sunan al-Tirmidzi, juz 3, hadis nomor 1206.

${ }^{11}$ Muhammad Ibn Ismail al-San'ani, Subulus Salam, juz 3, (Mesir: Maktabah al-Halabi, 1960), hlm. 38.
} 
Secara umum riba diklasifikasikan menjadi dua, yakni riba fadhal dan riba nasi'ah. Imam Ibn Qayyim al-Jauzi menyebut riba nasi'ah dengan riba jali dan riba fadhal dengan riba khafiy. Riba jaliy diharamkan karena ada kemudharatan yang sangat besar, pasti dan jelas. Sedangkan riba khafiy diharamkan karena ia merupakan wasilah atau jalan perantara kepada terjadinya riba jaliy. ${ }^{12}$ Sementara itu ulama Syafi'iyah mengklasfikasikan riba menjadi tiga, yakni riba fadhal, riba al-yad, dan riba nasi'ah. ${ }^{13}$

\section{(1) Riba Fadhal}

Menurut Wahbah Zuhaili, riba fadhal adalah tambahan benda dalam akad jual beli (tukar menukar yang menggunakan ukuran syara' (timbangan) yang sama jenis barangnya. Sedangkana menurut Sayid Sabiq, riba fadhal adalah jual beli uang dengan uang atau makanan dengan makanan yang disertai dengan kelebihan atau tambahan. ${ }^{14}$

Dari beberapa definisi tersebut dapat dipahami bahwa esensi sebenarnya dari riba fadhal adalah tambahan yang disyaratkan dalam tukar menukar barang yang sejenis (jual beli barter) tanpa adanya imbalan untuk tambahan tersebut. Misalnya menukar beras yang sama jenisnya 10 kilogram dengan beras 12 kilogram. Dan tambahan beras 2 kilogram tersebut tidak ada imbalannya. Karena itu dalam pelaksanaan jual beli disyaratkan bahwa tukar menukar barang yang sejenis ukurannya haruslah sama, baik takarannya maupun timbangannya. Jika terdapat kelebihan yang disyaratkan dalam perkanjian maka hal itu termasuk dalam kategori riba fadhal.

\section{(2) Riba Al-Yad}

Riba model ini hanya dikenal di kalangan mazhab Syafi'iyah. Dalam mazhab Hanafiyah riba al-yad termasuk dalam kelompok riba nasi'ah. Mereka menyebutnya dengan istilah "fadhul 'ain 'ala al-dain (kelebihan barang atas hutang)". Wahbah Zuhaili menjelaskan pengertian riba al-yad sebagai "Jual beli atau tukar menukar dengan cara mengakhirkan penerimaan kedua barang yang ditukarkan atau salah satunya tanpa menyebutkan masanya. Yakni terjadinya jual beli atau tukar menukar dua barang yang berbeda jenisnya, seperti gandum dengan jagung tanpa dilakukan penyerahannya di majelis akad." 15 Dari definisi tersebut dapat dipahami bahwa riba alyad adalah riba yang terjadi karena berpisahnya salah saorang dari dua pihak dari majelis akad sedangkan barang belum diserahkan. Dikatakan riba karena ketika barang yang diakadkan belum diserahkan, maka akan ada kemungkinan terjadinya harga barang yang diakadkan tersebut berkurang atau bertambah, kemungkinan berkurang atau bertambahnya nilai jual barang yang diakadkan tersebut jika terjadi pada saat penyerahan barang yang diakadkan setelah salah satu pihak yang bertransaksi meninggalkan majelis akad, maka itu menjadi riba yang dikenal dengan riba al-yad.

\section{(3) Riba Nasi'ah}

Para ulama Hanafiyah mendefinisikan riba nasi'ah sebagai kelebihan tunai atas tempo dan kelebihan barang atas hutang di dalam barang yang ditakar atau ditimbang ketika berbeda jenisnya, atau di dalam barang yang tidak ditakar atau ditimbang ketika jenisnya sama. Dengan kata lain, riba nasi'ah adalah menjual suatu barang dengan barang yang sama jenisnya, atau dengan barang yang tidak sama dengan dilebihkan takaran atau timbangannya sebagai imbalan diakhirkannya penukaran, atau tanpa tambahan seperti menjual satu kilogram kurma yang penyerahannya dilakukan secara langsung (di majelis akad) dengan satu kilogram kurma yang penyerahannya bertempo. Definisi yang lebih jelas tentang pengertian riba nasi'ah adalah seperti

\footnotetext{
${ }^{12}$ Ibn Qayyim al-Jauzi, I'lamul Muwaqi'in, juz 2 (Beirut: Dar al-Fikr, 1977), hlm. 135.

${ }^{13}$ Aul Abbas al-Ramli, Nihayah al-Muhtaj, juz 3, (Beirut: Dar al-Fikr, 2004), hlm. 424.

${ }^{14}$ Sayid Sabiq, Fiqh Sunnah, juz 3, (Beirut: Dar alikr, 1981), hlm. 178.

15 Wahbah Zuhaili, Fiqh Islam wa Adillatuh, juz 4, (Damaskus: Dar al-Fikr, 1989), hlm. 674.
} 
apa yang diungkapkan oleh Sayid Sabiq, yakni "Tambahan yang disyaratkan yang diambil oleh orang yang memberikan hutang dari orang yang menerima hutang sebagai imbalan atas ditundanya pembayaran." 16

Berdasarkan definisi tersebut dapat dipahami bahwa riba nasi'ah adalah tambahan yang dituntut oleh pemberi hutang kepada pihak yang berhutang sebagai imbalan atas penundaan waktu pembayaran hutang tersebut. Riba nasi'ah inilah yang seringkali terjadi di zaman jahiliyah dimana ayat-ayat riba turun dalam konteks riba nasi'ah sudah biasa dipraktikkan oleh masyarakat pada masa itu. Riba nasi'ah hukumnya haram berdasarkan al-Qur'an dan hadis. Menurut pendapat yang lain, seperti Ibn Abbas, Usamah bin Zaid, Zubair dan yang lainnya, riba yang diharamkan oleh al-Qur'an hanya riba nasi'ah berdasarkan hadis yang diriwayatkan oleh aBukhari dari Usamah bin Zaid bahwa Rasulullah saw bersabda "Tidak ada riba kecuali nasi'ah.",17

\section{B. Tinjauan Maqashid Syariah}

Untuk menganalisis masalah hukum bunga bank dengan menggunakan perspektif maqashid syari'ah ini penulis hanya akan menggunakan konsep maqashid syari'ah dari tingkat kepentingannya seperti yang telah dijelaskan konsepnya pada bab sebelumnya. Hal ini dilakukan untuk membatasi luasnya cakupan maqashid syari'ah serta untuk membatasi objek kajian agar hasil kajian dapat difokuskan dan dipahami secara jelas.

Seperti yang telah dijelaskan pada bab sebelumnya, maqâshid al-syari'ah bentuk ini dibedakan menjadi tiga, yaitu (1) maslahah level al-darûrât, (2) maslahah level al-hâjât, dan (3) maslahah level al-tahsînat/al-tazyînat. Masing-masing bagian disertai oleh maslahah penyempurna/pelengkap (takmilah/tatimmah). Pemeliharaan lima tujuan/prinsip dasar (al-usûl al-khamsah) yang berada pada level al-darûrât merupakan level terkuat dan tertinggi dari maslahah. Kelima tujuan/prinsip dasar mencakup (1) memelihara agama (hifz al-dîn), (2) memelihara jiwa (hifz al-nafs), (3) memelihara akal pikiran (hifz al-'aql), (4) memelihara keturunan (hifz al-nasl), dan (5) memelihara harta kekayaan (hifz al-mâl). ${ }^{18}$ Pandangan al-Gazâli tentang al-usûl al-khamsah ini disempurnakan lagi oleh Syihâb al-Dîn al-Qarafi dengan menambahkan satu tujuan/prinsip dasar lagi, yakni memelihara kehormatan diri (hifz al-'ird) meskipun diakui sendiri oleh al-Qarafi bahwa hal ini menjadi bahan perdebatan para ulama. ${ }^{19}$

Pada bagian ini penulis tidak akan melihat hukum bunga bank dari semua perspektif, melainkan hanya akan menggunakan konsep memelihara jiwa (hifz al-nafs) dan memelihara harta kekayaan ( hifz al-mâl) sebagai landasan analisisnya. Karena masalah bunga bank berkaitan erat dengan masalah keuangan, sedangkan masalah keuangan berkaitan secara langsung dengan kebutuhan hidup manusia.

Di atas telah disebutkan bahwa hukum bunga bank terbagi menjadi tiga yakti haram, halal, dan syubhat. Namun dalam kajian ini penulis hanya akan melihat hukum haram dan halalnya bunga bank dari tinjauan teori maqashid syari'ah. Jadi yang hendak dijelaskan adalah bagaimana bunga bank itu jika hukumnya haram jika dilihat dari tujuan-tujuan syari'ah, dan bagaimana jika hukumnya halal, dari kedua hukum tersebut manakah yang lebih sejalan dengan maqashid syari'ah.

\section{(1) Hukum Bunga Bank Perspektif Hifz Al-Nafs (Memelihara Jiwa)}

\footnotetext{
16 Sayid Sabiq, Fiqh Sunnah, juz 3, hlm. 672.

17 Shahih Bukhari, juz 2, hadis nomor 2069.

${ }^{18}$ Ibid, hlm. 417.

19 Syihâb al-Dîn al-Qarafi, Syarh Tanqîh al-Fusûl fi Ikhtisâr al-Mahsûl fi al-Ushûl, (Kairo: Al-Matba'ah alKhairiyyah, $1307 \mathrm{H}$ ).
} 
Sebagaimana telah dijelaskan bahwa bank merupakan lembaga keuangan yang fungsi utamanya adalah menerima dan menyalurkan dana. Penerimaan dana dari masyarakat selalu dihubungkan dengan penyalurannya kepada oranng atau lembaga yang memerlukan dana itu. Besar bunga yang diberikan oleh bank kepada pemasok modal disesuaikan dengan bunga yang dikenakan kepada peminjam dari bank. Selisih antara bunga yang diberikan kepada pemasok modal dan bunga yang dikenakan kepada peminjam merupakan keuntungan bank itu sendiri. Biasanya bank hanya akan memberikan kredit kepada orang atau lembaga yang diduga kuat dapat mengembangkan usahanya, dan bukan untuk keperluan hidup sehari-hari. Dengan kata lain, bank hanya memberikan pinjaman yang bersifat produktif, bukan konsumtif. Karena itu wajar jika pemilik modal dan bank mendapatkan keuntungan seiring dengan keuntungan yang akan diperoleh pengusaha yang meminjam modal. Sedangkan bagi orang yang memerlukan bantuan keuangan untuk biaya kebutuhan harian atau biaya pengobatan, tidak selayaknya menggunakan jasa bank dengan sistem bunga itu. Di sini perlu ada lembaga sosial yang menyediakan dana dan bersifat non-profit. Jika kepada orang yang disebut terakhir ini dibebankan bunga, maka kemungkinan adanya unsur pemerasan yang menjadi illat haramnya riba menjadi lebih besar. Karena itu, pembebanan tambahan atas pokok peminjam menjadi riba, sebagaimana dikehendaki oleh al-Qur'an.

Betapapun kredit dari bank itu dimaksudkan untuk usaha yang bersifat produktif, namun harus segera ditambahkan bahwa bunga yang dibebankan kepada debitur tidak melebihi batasbatas kewajaran, apalagi berlipat ganda. Pemerintah Republik Indonesia dalam hal ini Bank Indonesia, telah menetapkan jumlah suku bunga maksimal, dengan maksud untuk mengontrol suku bunga yang diberikan oleh bank-bank yang ada di Indonesia, sehingga akan terhindar dari suku bunga yang tidak wajar. Jika suku bunga itu melebihi batas kewajaran, apalagi berlipat ganda, seperti yang berlangsung pada masa jahiliyah, maka sudah dapat dipastikan bahwa bunga bank itu menjadi haram. Harus dipahami bahwa suku bunga yang melebihi batas kewajaran sebagaimana ditetapkan pemerintah akan membawa kepada penghisapan orang kaya terhadap orang yang lemah ekonominya. Itulah illat dari dilarangnya riba.

Apabila dilakukan pengamatan secara seksama, suku bunga yang diberikan bank kepada pemasok modal atau peminjam modal tidak dapat dilepaskan dari masalah nilai riil mata uang yang dipinjamkan. Di Indonesia biasanya tingkat inflasi hamper mendekati $10 \%$ per tahun. Keadaan ini menunjukkan nilai riil mata uang rupiah mengalami penyusutan kurang lebih $10 \%$ setiap tahun. Jika pemasok modal meminjamkan uangnya kepada bank, untuk kemudian disalurkan kepada pengusaha tanpa disertai tambahan apapun, berarti bank dan pengusaha telah berbuat aniaya (dhalim) kepada orang yang memiliki uang (pemasok modal). Semakin lama uang itu dipinjamkan, semakin menurut nilai riil uang tersebut. Keadaan seperti inilah yang tidak dikehendaki oleh firman Allah "la tadhlimuna wala tudhlamun". Pernyataan ini dikemukakan dengan maksud untuk menggambarkan bahwa tidak setiap tambahan atau kelebihan itu dinyatakan riba. Memang harus diakui bahwa jumlah inflasi setiap tahun selalu lebih kecil daripada suku bunga pertahun yang diberikan oleh bank. Selebihnya merupakan konpensasi resiko bagi kreditor. Belum lagi jika masalahnya tertuju kepada mata uang asing yang mempunyai nilai tukar yang tinggi dan constant. Atas dasar realitas yang telah diuraikan di atas tampaknya penulis lebih sepakat dengan kehalalan hukum bunga bank.

Kembali kepada pokok masalah dalam sub-tema ini, yakni kaitan hukum bunga bank dengan konsep hifz al-nafs (memelihara jiwa), dalam pandangan penulis hukum halalnya bunga bank lebih sejalan dengan konsep hifz al-nafs (memelihara jiwa) daripada hukum haramnya. Alasan penulis sederhana, yaitu dengan kehalalan bunga bank maka bank-bank yang menerapkan 
sistem bunga akan tetap dapat beroperasi dan akan dapat menggaji karyawannya sehingga mereka dapat memberi nafkah keluarganya. Kepada para nasabah penyimpan dana dapat terjamin dananya sehingga tidak khawatir kekurangan hidupnya. Demikian pula para nasabah peminjam dana akan dapat mengembangkan usahanya dengan bantuan pinjaman modal dari bank untuk memperbesar usahanya sehingga dapat tercapai kemakmuran yang tentunya akan berimbas pada kesejahteraan hidup minimal untuk keluarganya. Hal ini tentu tidak akan terjadi jika bunga bank diharamkan.

Karena itu dalam konteks hifz al-nafs (memelihara jiwa), hukum kehalalan bunga bank dapat ditempatkan pada tingkatan dharuriyat atau setidaknya hajiyat, karena dampaknya menyangkut kualitas hidup pihak bank, nasabah atau masyarakat, dan juga pemerintah.

Apabila dilihat dari tingkatan kemaslahatannya, dalam konsep hifz al-nafs (memelihara jiwa), terdapat tiga tingkatan, yaitu: (a) Memelihara jiwa dalam tingkatan dharuriyah, misalnya disyariatkannya kewajiban memenuhi kebutuhan pokok yang dibutuhkan oleh manusia seperti kebutuhan akan makanan yang sehat demi keberlangsungan hidup. Apabila kebutuhan pokok tersebut tidak terpenuhi atau diabaikan, maka akan berakibat pada terancamnya eksistensi kehidupan. Karena itu kebutuhan dalam tingkatan ini haruslah diupayakan dengan berbagai cara yang dibenarkan oleh syariah Islam. (b) Memelihara jiwa dalam tingkatan hajiyat, yaitu usaha untuk memenuhi kebutuhan-kebutuhan jiwa yang apabila tidak terpenuhi sebenarnay tidak akan membahayakan eksistensi jiwa tetapi akan menyulitkan terhadap upaya pemeliharaan jiwa. Misalnya dibolehkannya bercocok tanam dan menikmati makanan yang halal dan bergizi, atau menyediakan sarana tempat tinggal yang bersih dan terjaga dari berbagai macam penyakit. Dan (c) Memelihara jiwa dalam tingkatan tahsiniyat, yaitu upaya pemenuhan kebutuhan yang sifatnya sebagai penyokong atas kebutuhan jiwa dalam tingkatan dharuriyah dan hajiyat. Apabila kebutuhan dalam tingkatan tahsiniyat ini tidak terpenuhi, tidak akan memnahayakan keberadaann kehidupan, tetapi hanya akan mempersulit tercapainya kebutuhan hajiyat saja. Misalnya makan dan minum dalam takaran yang tepat, istirahat tepat waktu dan teratur, dan sebagainya.

Apabila dilihat dari konsep tingkatan hifz al-nafs (memelihara jiwa) tersebut di atas, masalah hukum kehalalan bunga bank menurut penulis dalam kondisi tertentu dapat berada pada ketiga tingkatan tersebut. Misalnya kepada seseorang yang memiliki anggota keluarga yang sakit parah dan membutuhkan biaya pengobatan dalam jumlah besar, dimana ia tidak mampu mendapatkan uang sebanyak yang dibutuhkan dalam saat tertentu, maka meminjam uang di bank dengan sistem bunga dimana ia berdasarkan perhitungannya akan mampu membayar hutang tersebut tepat pada waktunya, adalah suatu kemaslahatan karena akan dapat menyelamatkan nyawa keluarganya yang sakit tersebut. Dan ini adalah hifz al-nafs (memelihara jiwa) dalam tingkatan dharuriyah. Adapun contoh hifz al-nafs (memelihara jiwa) dalam tingkatan hajiyat adalah kredit perumahan dengan memanfaatkan jasa bank dengan sistem bunga. Atau kredit multiguna untuk biaya pendidikan. Kebutuhan akan tempat tinggal adalah sama pentingnya dengan kebutuhan akan pendidikan, meskipun ketiadaannya tidak secara langsung mengancam eksistensi jiwa, tetapi keduanya merupakan kebutuhan dalam tingkatan hajiyat dimana apabila tidak dipenuhi maka akan mempersulit upaya pemeliharaan kehidupan. Sedangkan contoh hifz al-nafs (memelihara jiwa) dalam tingkatan tahsiniyat misalnya seseorang meminjam sejumlah uang di bank dengan sistem bunga untuk keperluan memperbesar usaha atau bisnisnya. Keperluan untuk memperbesar usaha bisnis bukanlah kebutuhan yang dharuriyat atau hajiyat, tetapi keberadaannya dapat menyokong terpenuhinya kebutuhan dalam kedua tingkatan di atasnya sebagaimana disebutkan. 


\section{(2) Hukum Bunga Bank Perspektif Hifz Al-Mâl (Memelihara harta)}

Dalam konteks ini penulis lebih sepakat dengan kehalalan bunga bank, karena apabila bunga bank dihukumi haram, maka dalam pandangan penulis berdasarkan konsep maqashid syari'ah hal ini tidak sejalan dengan konsep hifz al-mâl (memelihara harta). Dalam sistem bunga, apabila peminjam dana adalah perorangan untuk keperluan konsumtif, maka beban bunga pinjaman tadi tentunya harus ditangani sendiri. Tetapi apabila peminjam dana adalah pedangang maka logislah apabila beban bunga pinjaman itu digeserkannya kepada harga barang yang dijual. Dari mekanisme kerja antar bank dengan nasabah inilah, baik nasabah peminjam maupun nasabah penyimpan, maka bank konvensional tidak dapat mempertahankan hidupnya, apalagi mengembangkannya tanpa mekanisme sistem bunga. Oleh karenanya, di sini dapat diambil sedikit pengertian segi positif bank dari sistem bunga yaitu dengan melalui sistem bunga, bank dapat melaksanakan aktivitas perbankannya.

Hukum halalnya bunga bank sepertinya juga sejalan dengan hifz al-mâl (memelihara harta) baik bagi nasabah peminjam maupun bagi nasabah penyimpan. Bagi nasabah peminjam, bunga bank selama dimanfaatkan untuk keperluan usaha yang dapat meningkatkan ekonominya tentunya bunga yang harus dibayar tidak akan memudharatkan baginya. Atau misalnya dana pinjaman digunakan untuk keperluan konsumtif seperti membangun rumah pun tidak dapat dikatakan bahwa bunga bank tersebut memerasnya, karena dengan itu nasabah peminjam juga diuntungkan dengan harga properti yang semakin hari semakin mahal. Jadi adanya bunga bank tentulah bukan merupakan bentuk pemerasan terhadap nasabah peminjam.

Apabila nasabah adalah nasabah penyimpan, maka hukum kehalalan bunga bank pun sejalan dengan konsep hifz al-mâl (memelihara harta), dimana seseorang tersebut dapat menyimpan hartanya dengan aman, hartanya dapat bertambah tanpa merugikan bank sebagai pihak yang bertanggung jawab sebagai pengelola uang nasabah penyimpan. Karena untuk menyimpan dan mengelola uang dalam jumlah besar, keberadaan bank sangat dibutuhkan.

Jadi dari sini dapat disimpulkan bahwa hukum keharaman bunga bank tidak sejalan dengan konsep hifz al-mâl (memelihara harta) baik bagi pihak bank, bagi nasabah peminjam atau debitur, juga bagi nasabah penyimpan. Sedangkan hukum kehalalan bunga bank menurut penulis sejalan dengan konsep hifz al-mâl (memelihara harta) baik bagi pihak bank, bagi nasabah peminjam atau debitur, juga bagi nasabah penyimpan.

Perlu dicatat bahwa kaitan hukum bunga bank dengan konsep hifz al-mâl (memelihara harta) tersebut dapat terjadi pada level hajiyat hingga level dharuriyat. Karena keharaman hukum bunga bank jika dikaitkan dengan konsep hifz al-mâl (memelihara harta) pada ranah hajiyat dan dharuriyat akan menyebabkan orang tidak diperbolehkan berhubungan dengan bank, meminjam dan menyimpan uang di bank konvensional, padahal saat ini hampir seluruh transaksi keuangan dari gaji hingga untuk keperluan ibadah sekalipun selalu berhubungan dengan bank yang menggunakan sistem bunga. Dan hukum keharaman bunga bank tidak saja dapat menyulitkan umat dalam bertransaksi ekonomi mereka, tetapi bisa jadi dapat menghilangkan kesempatan untuk meninggatkan ekonomi masyarakat.

Apabila dilihat dari tingkatan kepentingan atau kemaslahatannya, jenis tujuan syariah hifz al-mâl (memelihara harta) tersebut memiliki tiga tingkatan yaitu: (a) Memelihara harta dalam tingkatan dharuriyat, adalah upaya pemeliharaan harta dari hilangnya atau berkurangnya karena sebab-sebab yang menyelisihi syariah Islam. Misalnya hilangnya harta karena penipuan, perampokan, pencurian serta sebab-sebab lainnya yang semisal. Karena itu syariah Islam memberikan aturan tentang kepemilikan harta beriktu larangan mengambil harta orang lain dengan cara yang tidak benar. (b) Memelihara harta dalam tingkatan hajiyat, yaitu upaya 
memelihara harta dengan jalan mengembangkannya agar tidak berkurang dengan cara-cara yang tidak melanggar aturan syariat islam. Misalnya melakukan pemeliharaan harta dengan cara bekerja untuk mendapatkan kekayaan, jual beli, mudharabah atau kerja sama bisnis, murabahah atau perniagaan, musaqah dan lain sebagainya. Tidak adanya pemeliharaan harta dalam tingkatan hajiyat ini tidak akan menyebabkan hilangnya eksistensi harta, tetapi akan mempersulit mewujudkan terpeliharanya eksistensi harta. Dan (c) Memelihara harta dalam tingkatan tahsiniyat, yaitu upaya pemeliharaan harta yang dilakukan demi kelancaran upaya pemeliharaan harta dalam tingkatan dharuriyat dan hajiyat. Misalnya berlaku jujur dalam berdagang, bekerja tepat waktu sesuai jam dan tidak bermalas-malasan, serta menghadirkan kepuasan terhadap orang yang menggunakan jasanya. Pemeliharaan harta dalam tingkatan ini tentunnya tidak akan mengancam pemeliharaan harta pada tingkatan dharuriyat dan hajiyat, tetapi dengan terpenuhinya pemeliharaan harta dalam tingkatan tahsiniyat tersebut akan mempermudah tercapainya pemeliharaan harta dalam tingkatan dharuriyat dan hajiyat.

Hukum kehalalan bunga bank apabila ditinjau dari ketiga konsep hifz al-mâl (memelihara harta) seperti yang telah dijelaskan di atas, maka akan dapat ditemukan relevansinya dalam ketiga tingkatan tersebut. Misalnya hifz al-mâl (memelihara harta) dalam tingkatan dharuriyat jika dikaitkan dengan hukum kehalalan bunga bank adalah bagi nasabah deposito maka uang yang disimpan di bank tidak akan berkurang sedikitpun dan bahkan dapat bertambah, karena tidak ada penipuan maupun pencurian dalam sistem perbankan. Sementara bagi pihak bank, adanya nasabah yang bertransaksi dan menyimpan uang di bank akan dapat membantu keberlangsungan operasional bank dan dengan demikian kegiatan ekonomi tetap dapat berjalan. Adapun hifz al-mâl (memelihara harta) dalam tingkatan hajiyat misalnya, bunga bank dibutuhkan untuk mengatasi kerugian akibat adanya inflasi mata uang, karena apabila sistem bunga ditiadakan maka pihak bank lah yang akan menanggung kerugian akibat inflasi tersebut. Demikian pula dengan nasabah penyimpan uang di bank, jika sistem bunga ditiadakan maka nasabah akan terkena dampak dari inflasi atau perubahan nilai mata uang yang lumrah terjadi di masa sekarang. Sedangkan hifz al-mâl (memelihara harta) dalam tingkatan tahsiniyat berkaitan dengan hukum kehalalan bunga bank misalnya adalah adanya pembayaran dan penagihan secara jujur dan disiplin yang dilakukan dalam sistem perbankan.

\section{KESIMPULAN}

Berdasarkan uraian hasil penelitian, penulis menemukan ada tiga pandangan ulama tentang hukum bunga bank, yaitu haram, halal, dan syubhat. Apabila ditinjau dari perspektif maqashid syari'ah, penulis menyimpulkan bahwa pendapat yang menghalalkan bunga bank lebih sejalan dengan maqashid syari'ah, yakni dalam hal hifz al-nafs (memelihara jiwa) dan hifz al-mâl (memelihara harta) daripada hukum keharamannya. Adapun hukum kehalalan bunga bank dalam hal hifz al-nafs (memelihara jiwa) dapat ditempatkan pada tingkatan dharuriyat atau setidaknya hajiyat, karena dampaknya menyangkut kualitas hidup pihak bank, nasabah atau masyarakat, dan juga pemerintah. Sedangkan hukum kehalalan bunga bank dalam hal hifz al-mâl (memelihara harta) tersebut dapat terjadi pada level hajiyat hingga level dharuriyat. Karena keharaman hukum bunga bank jika dikaitkan dengan konsep hifz al-mâl (memelihara harta) pada ranah hajiyat dan dharuriyat akan menyebabkan orang tidak diperbolehkan berhubungan dengan bank, meminjam dan menyimpan uang di bank konvensional, padahal saat ini hampir seluruh transaksi keuangan dari gaji hingga untuk keperluan ibadah sekalipun selalu berhubungan dengan bank yang menggunakan sistem bunga. Dan hukum keharaman bunga bank tidak saja dapat menyulitkan 
umat dalam bertransaksi ekonomi mereka, tetapi bisa jadi dapat menghilangkan kesempatan untuk meninggatkan ekonomi masyarakat.

\section{DAFTAR PUSTAKA}

Ali, Hasan, Masail Fiqhiyyah: Zakat, Pajak, Asuransi dan Lembaga Keuangan, Jakarta: Raja Grafindo Husada, 1996.

Al-Jauzi, Ibn Qayyim, I’lamul Muwaqi’in, juz 2 Beirut: Dar al-Fikr, 1977.

Al-Kilânî, Abd al-Rahmân Ibrahîm, Qawâ'id al-Maqâshid 'inda al-Imâm al-Shâthibî: 'Aradhan wa Dirâsatan wa Tahlîlan, Damshiq: IIIT, 2000.

Al-Muqrî, Ahmad bin Muhammad bin Alî al-Fâyûmî, Al-Mishbâh al-Munîr fî Gharîb al-Sharh al-Kabîr li al-Rafi'’̂, Libanon: Maktabah Lubnan, 1987.

Al-Qarafi, Syihâb al-Dîn, Syarh Tanqîh al-Fusûl fi Ikhtisâr al-Mahsûl fi al-Ushûl, Kairo: AlMatba'ah al-Khairiyyah, $1307 \mathrm{H}$.

Al-Qardhawi, Yusuf, Dirasah fi Fiqih Maqâshid Syari'ah: Baina al-Maqâshid al-Kulliyyah wa an-Nushush al-Juz'iyyah, Kairo: Dar as-Syuruq, 2006.

Harahap, Syabirin Bunga Uang dan Riba Dalam Hukum Islam, Jakarta: Pustaka al-Husna, 1984.

Jamil, Fathurrahman, Metode Ijtihad Muhamamdiyah, Jakarta: Logos, 1995.

Kasmir, Bank dan Lembaga Keuangan Lainnya, Jakarta: RajaGrafindo Persada, 2008

Marzuki, Peter Mahmud, Penelitian Hukum, Jakarta: Kencana, 2005.

Sunggono, Bambang, Metodologi Penelitian Hukum, Jakarta: Rajagrafindo, 1997.

Thohari, Chamim, Argumentasi Ibn Hazm: Dekonstruksi Kehujjahan Qiyas Sebagai Metode Penetapan Hukum Islam, Jurnal Istinbath, Vol. 13 No. 1, Mei 2016.

Umar, Umar bin Shâlih bin, Maqâshid al-Sharî'ah 'inda al-Imâm al-'Izz bin 'Abd al-Salâm, Urdun: Dâr al-Nafâ' is li al-Nahr wa al-Tawzi, 2003.

Zuhaili, Wahbah, Fiqh Islam wa Adillatuh, juz 4, Damaskus: Dar al-Fikr, 1989.

Zuhdi, Masjfuk, Masail Fiqhiyah, cet VIII, Jakarta: Surya Grafindo, 1998. 